\title{
UJI TOKSISITAS EKSTRAK TUMBUHAN AGERATUM CONYZOIDES L. TERHADAP PERTUMBUHAN DAN FISIOLOGI DARAH MENCIT
}

\author{
Kusnadi , Any Fitriani dan Hernawati \\ Universitas Pendidikan Indonesia, J1. Dr. Setiabudhi 229 Bandung
}

\begin{abstract}
Abstrak
Telah dilakukan penelitian tentang uji toksisitas ekstrak tumbuhan Ageratum conyzoides L. dari ekstrak akar dan daun terhadap pertumbuhan dan fisiologi darah mencit. Tujuan penelitian untuk menganalisis pengaruh pemberian ekstrak akar dan daun Ageratum conyzoides L. terhadap fisiologis darah (jumlah darah merah dan darah putih) mencit, berat badan, dan berat organ (hati dan ginjal). Rancangan penelitian menggunakan model rancangan acak kelompok (RAK), faktor pertama adalah dosis (kontrol, 14, 28, 42, 56, $70 \mathrm{mg} / \mathrm{kg} \mathrm{BB}$ ) ekstrak akar dan daun Ageratum. conyzoides L., faktor kelompok kedua yaitu hari pengamatan ke-1, 3, 5, dan 7. Mencit yang digunakan berumur tiga bulan. Hasil pengamatan menunjukkan bahwa pemberian ekstrak daun dan akar Ageratum conyzoides $\mathrm{L}$. sebesar $14,28,42,56,70 \mathrm{mg} / \mathrm{kg}$ BB tidak mempengaruhi berat badan mencit, darah merah, darah putih, hemoglobin, berat ginjal dan berat hati. Pemberian ekstrak daun dan akar Ageratum conyzoides L. pada hari ke-1, 3, 5 dan 7 tidak berpengaruh terhadap berat badan. Jumlah sel darah merah meningkat pada hari ke-5 $\left(3,443 \times 10^{6} / \mathrm{mm}^{3}\right)$. Jumlah sel darah merah menurun pada hari ke-3 namun meningkat kembali pada hari ke-5 dan 7. Jumlah darah putih tidak berpengaruh pada pemberian ektrak daun, namun pada ekstrak akar menurun. Kadar hemoglobin menurun seiring waktu pengamatan, namun masih pada batas yang normal. Perbandingan pemberian ekstrak akar dan daun Ageratum conyzoides $\mathrm{L}$. pada dosis yang sama memperlihatkan hasil yang berbeda. Kesimpulan adalah pemberian ekstrak daun dan akar Ageratum conyzoides L. tidak mengganggu berat badan, jumlah sel darah merah, jumlah sel darah putih, hemoglobin dan berat organ (hati dan ginjal).
\end{abstract}

Kata kunci : Ageratum conyzoides L., sel darah merah, sel darah putih, hemoglobin, hati, ginjal.

\begin{abstract}
We have examined the toxicity of Ageratum conyzoides extract from root extract and leaf on the growth and blood physiology in mice. The objectives of this research are to analize the effect of Ageratum conyzoides $\mathrm{L}$. on blood physiology (the number of red blood cells and white blood cells), weight of mice, and organ weight (liver and kidney). The design of experiment used randomized complete block design, first factor is the doses (control, $14,28,42,56,70 \mathrm{mg} / \mathrm{kg}$ of weight) roof and leaf Ageratum conyzoides L. extracts, second factor is the days of obeservations $(1,3,5$, and 7$)$. The mice aged three months. The results showed the extracts of leaf and root Ageratum conyzoides L. in $14,28,42,56,70 \mathrm{mg} / \mathrm{kg}$ of weight have not affected on the mice weight. The number of red blood cells increased $\left(3,443 \times 10^{6} / \mathrm{mm}^{3}\right)$ on the 5th days observed. The number of red blood cell decreased on 3rd day observation, but it could increase on 5th and 7th days observation. The number of white blood cell had not affected in this research, but it decreased on the root extracts treatment. The hemoglobin levels decreased with time of observation, but still in normal range. The comparison of root and leaf Ageratum conyzoides $\mathrm{L}$. extracts in the same doses indicated the different results. We concluded that the root and leaf Ageratum conyzoides L extracts had not affected weight, number of red blood cells, number white blood cells, hemoglobin, and organ weight (liver and kidney).
\end{abstract}

Keywords: Ageratum conyzoides, red blood cell, white blood cell, hemoglobin, liver, kidney.

\section{PENDAHULUAN}

Obat tradisional telah lama digunakan masyarakat Indonesia dan merupakan suatu aset nasional. Semakin meningkatnya harga obat dan terbatasnya daya beli masyarakat, menjadikan obat tradisional sebagai suatu alternatif untuk tujuan menjaga kesehatan maupun untuk pengobatan sendiri (Jamal dan Suhardi, 1999). Penggunaan obat tradisi-onal yang berasal dari tanaman berdasarkan keputusan menteri kesehatan RI harus memiliki syarat-syarat tertentu 
antara lain dapat dibuktikan khasiat dan keamanannya.

Di Indonesia, pengobatan tradisional telah berlangsung sejak dahulu dan digunakan secara turun-temurun. Terlebih lagi dewasa ini di masyarakat berkembang isu back to nature membuat penggunaan obat tradisional cenderung semakin meningkat. Sementara itu banyak orang beranggapan bahwa penggunaan tanaman obat relatif lebih aman dibandingkan obat sintesis. Walaupun demikian bukan berarti tanaman obat tidak memiliki efek samping yang merugikan bila penggunaannya kurang tepat. Ketepatan itu menyangkut tepat dosis, cara, dan waktu penggunaan, serta pemilihan bahan ramuan yang sesuai dengan indikasi penggunaannya. Obat tradisional biasanya digunakan untuk memelihara kesehatan, mencegah penyakit, mengobati penyakit maupun memulihkan kesehatan (Firdaus, 2010).

Masyarakat Indonesia telah menggunakan obat tradisional sebagai salah satu upaya dalam penanggulangan masalah kesehatan jauh sebelum layanan kesehatan formal dengan obat-obat modernnya menyentuh masyarakat. Dalam satu penelitian diungkapkan salah satu alternatif dalam mencari senyawa baru adalah dengan melakukan penelitian secara fitokimia yang sekaligus sebagai langkah awal untuk mengetahui kandungan aktif biologis yang berasal dari tumbuhan obat. Penggunaan tanaman sebagai obat sudah dikenal luas baik di negara berkembang maupun negara maju (Hasibuan dan Nainggolan, 2007).

Salah satu tanaman obat yang banyak digunakan adalah Ageratum. Di Indonesia, Ageratum conyzoides L. (bandotan) merupakan tumbuhan liar dan lebih dikenal sebagai tumbuhan pengganggu (gulma) di kebun dan di ladang. Bagian yang digunakan untuk obat adalah herba (bagian di atas tanah) dan akar. Herba bandotan berkhasiat untuk pengobatan demam, malaria, sakit tenggorok, radang paru, radang telinga tengah, perdarahan rahim, luka berdarah, mencegah kehamilan, tumor rahim, dan perawatan rambut (Retno, 2009). Kandungan senyawa daun tumbuhan ini adalah minyak atsiri, alkaloid dan kumarin (Heyne, 1987).

Penelitian tentang Ageratum conyzoides ini banyak dilakukan, misalnya penelitian Pasaribu (2009) mengenai uji bioaktivitas metabolit sekunder dari tumbuhan Ageratum conyzoides, yaitu penentuan sifat kimia fisika senyawa alkaloid hasil isolasi dari daun bandotan ini, dan penelitian Hasibuan dan Nainggolan (2007) mengatakan ekstrak ethanol daun Ageratum conyzoides ini mempunyai aktivitas antimikroba. Penggunaan antibiotik dan bahan kimia secara terus menerus dapat menimbulkan efek samping baik terhadap lingkungan maupun manusia sebagai konsumen. Pemberian antibiotik secara berlebihan dapat menyebabkan resistennya mikroorganisme patogen, dan bahkan dapat menimbulkan galur baru, sedangkan bahan kimia dapat merusak lingkungan yang sulit didegradasi (Baticados dan Paclibare dalam Syawal, 2008). Berdasarkan uraian di atas tujuan penelitian untuk menganalisis pengaruh pemberian ekstrak akar dan daun Ageratum. conyzoides L. terhadap gambaran fisiologis darah (jumlah sel darah merah, jumlah sel darah putih) mencit, berat badan, dan berat organ (hati dan ginjal).

\section{METODE}

Desain penelitian yang digunakan pada penelitian ini adalah dengan menggunakan Rancangan Acak Kelompok (RAK). Hewan uji yang akan digunakan dalam penelitian ini adalah mencit betina yang berumur 3 bulan. Terdapat enam perlakuan yang diberikan pada mencit betina yakni dosis alkaloid Ageratum conyzoides L. $14 \mathrm{mg} / \mathrm{kg} ; 28 \mathrm{mg} / \mathrm{kg} ; 42 \mathrm{mg} / \mathrm{kg} ; 56 \mathrm{mg} / \mathrm{kg}$; dan $70 \mathrm{mg} / \mathrm{kg}$, ditambah dengan kontrol. Ekstrak alkaloid yang digunakan dilarutkan dengan menggunakan pelarut metanol. Alkaloid yang akan diinjeksikan kepada mencit betina dilarutkan menggunakan larutan salin normal (Ita, 2007).

Mencit yang digunakan dibagi menjadi enam kelompok dosis pemberian alkaloid Ageratum conyzoides L. Sebelum ke tahap perlakuan, seluruh hewan percobaan diaklimatisasi selama satu minggu. Parameter yang diukur adalah berat badan mencit, jumlah sel darah (leukosit, eritrosit, trombosit, kadar hemoglobin dan hematokrit), berat hati dan ginjal. Pengambilan data dilakukan pada hari ke 0,3, 5 dan 7 .

\section{Pembuatan Alkaloid Akar Ageratum conyzoides $\mathbf{L}$.}

Akar Ageratum conyzoides L. dibersihkan dari sisa tanah dan dikeringkan dengan cara diangin-anginkan. Selanjutnya sampel dihaluskan dan dilarutkan dengan pelarut metanol sampai tercampur rata dan terendam. Campuran 
tersebut disaring, kemudian residunya dibilas dua kali dengan metanol sebanyak $10 \mathrm{ml}$. Campuran metanol diuapkan dengan titik didih yang lebih rendah dari titik didih metanol (60 ${ }^{0} \mathrm{C}$ ). Residu hasil penguapan dicampur dengan $\mathrm{HCl}$ 0,1 M. Campuran tersebut dibilas dua kali dengan diklorometana sebanyak $25 \mathrm{ml}$ dalam corong pemisah.

Di dalam corong pemisah akan terbentuk 3 fase, fase yang diambil adalah fase yang paling atas (fase yang memiliki fase paling asam). Fase tersebut kemudian dibasakan dengan larutan $\mathrm{NaOH}$ hingga $\mathrm{pH}$ 10. Setelah fase asam berubah menjadi fase basa, dibilas dengan $25 \mathrm{ml}$ diklorometana sebanyak 3 kali. Setiap kali bilasan, fraksi yang diambil adalah fraksi diklorometan. Kumpulan fraksi diklorometan diuapkan dengan titik didih dibawah titik didih diklorometan (Fitriani, 1998). Pelarut residu menggunakan larutan salin normal $(0,9 \%)$ sebanyak $1 \mathrm{ml}$. Hasil ekstraksi lalu disimpan ke dalam botol film dengan kemasan yang baik dan disimpan di dalam lemari es (suhu $\pm 4^{\circ} \mathrm{C}$ ).

\section{Penentuan Dosis Alkaloid}

Dosis alkaloid Ageratum conyzoides L. diberikan berdasarkan penelitian sebelumnya yaitu pemberian alkaloid pada tikus dengan dosis $200 \mathrm{mg} / \mathrm{kg}$ (Ita, et al. 2007). Dengan menggunakan tabel perbandingan luas permukaan tubuh hewan untuk mengkonversi dosis tikus dengan berat badan 150-250 g ke mencit dengan berat badan $25 \mathrm{~g}$, didapatkan nilai konversi sebesar 0,14 . Penghitungan konversi dosis alkaloid untuk mencit dengan berat $25 \mathrm{~g}$ adalah $28 \mathrm{mg} / \mathrm{kg}$. Dosis alkaloid kemudian dimodifikasi untuk mencit yaitu sebesar 14 $\mathrm{mg} / \mathrm{kg} ; 28 \mathrm{mg} / \mathrm{kg} ; 42 \mathrm{mg} / \mathrm{kg} ; 56 \mathrm{mg} / \mathrm{kg} ; 70$ $\mathrm{mg} / \mathrm{kg}$ dan kontrol negatif (tanpa pemberian alkaloid). Volume penyuntikan untuk mencit umumnya adalah: $1 \mathrm{ml} / 100 \mathrm{~g}$ bobot badan. Mencit pada penelitian ini seberat $25 \mathrm{~g}$ maka volume penyuntikan alkaloid sebanyak 0.4 $\mathrm{ml} / 25 \mathrm{~g}$ berat badan mencit. Penyuntikan alkaloid diberikan secara intraperitonial.

\section{Penghitungan jumlah sel darah :}

1. Jumlah sel darah putih (Leukosit) : menggunakan Hemositometer Neubauer (skala pipet 0,5-1,0-11) dengan larutan pengencer yaitu larutan Turk. Untuk menghitung sel darah putih menggunakan 4 kotak yang terletak di keempat sudut kamar hitung (yang masing-masing terdiri dari 16 kotak). Satu kotak mempunyai luas $1 \mathrm{~mm}^{2}$ dan dalamnya $1 / 10 \mathrm{~mm}$ jadi ruangan untuk menghitung jumlah sel darah putih seluruhnya adalah $(4 \times 1 \times 1 / 10) \mathrm{mm}^{3}=$ $4 / 10 \mathrm{~mm}^{3}$. Faktor pengencer : darah 0,5 larutan pengencer sampai 11 dikurangi 1 bagian yang tidak ikut tercampur sehingga pengen-cerannya 20x, maka

Jumlah BDP $/ \mathrm{mm}^{3}$ darah $=20 \times \frac{10}{4} \times \mathrm{b}$ sel darah $\quad=\mathrm{b} \times 50 \mathrm{sel}$

2. Jumlah sel darah merah (Eritrosit) : menggunakan Hemositometer Neubauer (skala pipet 0,5-1,0-101) dengan larutan pengencer yaitu larutan Hayem. Untuk menghitung sel darah merah menggunakan 5 kotak kecil yang terletak di empat sudut kamar hitung dan satu ditengah (yang masing-masing kotak kecil terdiri dari 16 kotak terkecil). Satu kotak kecil mempunyai luas $(16 \times 1 / 400) \mathrm{mm}^{2}$ dan dalamnya $1 / 10$ $\mathrm{mm}$ jadi ruangan untuk menghitung jumlah sel darah merah seluruhnya adalah (16 $\mathrm{x}$ $1 / 400 \times 1 / 10) \mathrm{mm}^{3}=1 / 50 \mathrm{~mm}^{3}$.

Faktor pengencer : darah 0,5 larutan pengencer sampai 101 dikurangi 1 bagian yang tidak ikut tercampur sehingga pengencerannya $200 x$, maka

Jumlah BDP $/ \mathrm{mm}^{3}$ darah $=200 \times 50 \times$ a sel darah $=$ a $\times 10^{4} \mathrm{sel}$

Kadar haemoglobin dalam darah : menggunakan metode Sahli. Darah dengan larutan $\mathrm{HCL} \quad 0,1 \quad \mathrm{~N}$ akan membentuk hematin yang berwarna coklat. Warna disamakan dengan warna standar Sahli dengan menggunakan aquadestilata sebagai pengencer.

\section{Pengukuran berat badan, hati dan ginjal}

Penimbangan berat dilakukan selama tujuh hari yaitu pada hari ke-1, 3, 5, dan 7. Pengukuran berat hati dan ginjal dilakukan pada hari ke-7 setelah perlakuan. Kemudian hati dan ginjal (dari sisa-sisa darah) dibersikan menggunakan $\mathrm{NaCl} 0.9 \%$ danditimbang menggunakan neraca timbangan analitik.

\section{HASIL DAN PEMBAHASAN}

Berdasarkan hasil penelitian ini telah didapatkan hasil berupa data dasar fisiologi darah mencit yang telah diberikan ekstrak Ageratum conyzoides L. dari akar dan daun melalui penyuntikan intraperitoneum. Adapun 
indeks darah yang dihitung yaitu sel darah merah (BDM), sel darah putih (BDP) dan hemoglobin. Di samping itu parameter lain yang dicatat adalah berat badan, berat organ hati dan ginjal.
Data hasil penimbangan berat badan mencit setelah diberikan ekstrak akar dan daun $A$. conyzoides $\mathrm{L}$ disajikan pada Tabel 1 dan Tabel 2.

Tabel 1 Rerata Berat Badan Mencit Setelah Diberi Ekstrak Akar Ageratum conyzoides L.

\begin{tabular}{|c|c|c|c|c|c|c|c|}
\hline \multirow{3}{*}{ Hari } & \multicolumn{6}{|c|}{ Berat Badan Mencit (g) } & \multirow{3}{*}{$\begin{array}{c}\text { Rerata } \\
\text { Hari }\end{array}$} \\
\hline & \multicolumn{6}{|c|}{ Dosis Ekstrak Akar (mg/kg BB) } & \\
\hline & 0 & 14 & 28 & 42 & 56 & 70 & \\
\hline 1 & 29,800 & 32,700 & 29,525 & 34,200 & 33,450 & 31,675 & $31,892^{\mathrm{a}}$ \\
\hline 3 & 27,675 & 31,225 & 29,375 & 34,450 & 32,800 & 31,225 & $31,125^{\mathrm{a}}$ \\
\hline 5 & 27,325 & 30,825 & 30,175 & 33,275 & 31,650 & 30,950 & $31,108^{\mathrm{a}}$ \\
\hline 7 & 28,550 & 31,025 & 31,175 & 32,975 & 31,425 & 31,650 & $30,700^{\mathrm{a}}$ \\
\hline $\begin{array}{c}\text { Rerata } \\
\text { Dosis }\end{array}$ & $28,338^{d}$ & $31,444^{\text {bc }}$ & $30,025^{\mathrm{c}}$ & $33,725^{\mathrm{a}}$ & $32,331^{\mathrm{ab}}$ & $31,375^{\mathrm{bc}}$ & \\
\hline
\end{tabular}

Pada tabel di atas dapat dilihat bahwa ratarata berat badan mencit setelah diberikan ekstrak akar A. conyzoides L. selama pengamatan yaitu hari ke-1, 3, 5,7 tidak menunjukkan perbedaan yang signifikan, artinya ekstrak akar $A$. conyzoides $\mathrm{L}$. tidak berpengaruh terhadap berat badan mencit. Namun apabila dilihat berdasarkan dosis pemberian ekstrak A. conyzoides L. maka dapat dilihat bahwa berat badan mencit yang diberikan ekstrak $A$. conyzoides $\mathrm{L}$. berbeda signifikan lebih berat dibandingkan dengan mencit kelompok kontrol. Selanjutnya esktrak $A$. conyzoides L. dengan dosis $42 \mathrm{mg} / \mathrm{kg} \mathrm{BB}$ menunjukkan peningkatan berat badan yang paling besar yaitu 33, $725 \mathrm{~g}$.

Pada Tabel 2 di atas dapat dilihat bahwa rata-rata berat badan mencit setelah diberikan ekstra daun A. conyzoides L. selama penga- matan yaitu hari ke-1, 3, 5,7 tidak menunjukkan perbedaan yang signifi-kan, artinya ekstrak daun A. conyzoides $\mathrm{L}$. tidak berpengaruh terhadap berat badan mencit. Apabila dilihat berdasarkan dosis pemberian eks-trak daun A. conyzoides $\mathrm{L}$. maka dapat dilihat bahwa berat badan mencit yang diberikan ekstrak daun $A$. conyzoides $\mathrm{L}$. pada dosis $14,28,56,70 \mathrm{mg} / \mathrm{kg}$ tidak berbeda signifikan lebih berat dibandingkan dengan mencit kelompok kontrol. Namun pada pemberian ekstrak daun $A$. conyzoides L. dosis 42 $\mathrm{mg} / \mathrm{kg}$, berat badan mencit terlihat berbeda signifikan lebih berat dibandingkan dengan kelompok kontrol. Selanjutnya esktrak $A$. conyzoides L. dengan dosis $42 \mathrm{mg} / \mathrm{kg} \mathrm{BB}$ menunjukkan peningkatan berat badan yang paling besar yaitu 31, $613 \mathrm{~g}$ dibandingkan dengan dosis yang lainnya.

Tabel 2 Rerata Berat Badan Mencit Setelah Diberi Ekstrak Daun Ageratum conyzoides L.

\begin{tabular}{|c|c|c|c|c|c|c|c|}
\hline \multirow{3}{*}{ Hari } & \multicolumn{6}{|c|}{ Berat Badan Mencit (g) } & \multirow{3}{*}{$\begin{array}{c}\text { Rerata } \\
\text { Hari }\end{array}$} \\
\hline & \multicolumn{6}{|c|}{ Dosis Ekstrak Akar (mg/kg BB) } & \\
\hline & 0 & 14 & 28 & 42 & 56 & 70 & \\
\hline 1 & 28,525 & 32,125 & 29,775 & 31,525 & 30,275 & 29,075 & $30,217^{\mathrm{a}}$ \\
\hline 3 & 29,650 & 28,725 & 28,125 & 31,650 & 30,575 & 26,425 & $29,192^{\mathrm{a}}$ \\
\hline 5 & 28,575 & 29,375 & 28,675 & 31,325 & 30,850 & 28,975 & $29,629^{a}$ \\
\hline 7 & 29,250 & 31,125 & 28,300 & 31.950 & 30,775 & 29,725 & $30,188^{\mathrm{a}}$ \\
\hline $\begin{array}{c}\text { Rerata } \\
\text { Dosis }\end{array}$ & $29,000^{\mathrm{ab}}$ & $30,338^{\mathrm{ab}}$ & $28,719^{\mathrm{b}}$ & $31,613^{\mathrm{a}}$ & $30,619^{\mathrm{ab}}$ & $28.550^{\mathrm{b}}$ & \\
\hline
\end{tabular}

Herba Ageratum conyzoides L. tidak berpengaruh terhadap berat badan mencit. Hal tersebut dikarenakan zat aktif dalam tanaman tersebut tidak bersifat toksik bagi mencit. Dalam hal ini pemberian ekstrak akar daun Ageratum conyzoides L. tidak berpengaruh terhadap perilaku makan mencit. Di samping itu diduga bahwa kandungan bahan aktif dalam $A$. conyzoides $L$. dapat meningkat metabolisme pada tubuh mencit. Menurut Fitriani (1998) menyatakan bahwa Ageratum conyzoi-des L. mengandung bahan aktif sterol dan steroid yang masih belum diketahui jenisnya. Telah diketahui bahwa sterol dan steroid merupakan bahan aktif yang dapat memicu metabolisme tubuh.

Data hasil perhitungan jumlah sel darah merah (BDM) mencit setelah diberikan ekstrak daun dan akar $A$. conyzoides $\mathrm{L}$. disajikan pada Tabel 3 dan Tabel 4. 
Tabel 3 Rerata Jumlah Sel Darah Merah Mencit Setelah Diberi Ekstrak Daun Ageratum conyzoides L.

\begin{tabular}{|c|c|c|c|c|c|c|c|}
\hline \multirow{3}{*}{ Hari } & \multicolumn{6}{|c|}{ Sel Darah Merah $\left(\times 10^{6} / \mathrm{mm}^{3}\right.$ darah) } & \multirow{3}{*}{$\begin{array}{c}\text { Rerata } \\
\text { Hari }\end{array}$} \\
\hline & \multicolumn{6}{|c|}{ Dosis Ekstrak Akar (mg/kg BB) } & \\
\hline & 0 & 14 & 28 & 42 & 56 & 70 & \\
\hline 1 & 2,5525 & 2,7350 & 2,3450 & 2,2675 & 2,7550 & 2,7375 & $2,5654^{\mathrm{b}}$ \\
\hline 3 & 3,4050 & 3,1225 & 3,1575 & 2,9425 & 2,7325 & 2,5025 & $2,9770^{\mathrm{ab}}$ \\
\hline 5 & 3,8575 & 4,2175 & 3,8875 & 2,8900 & 3,2200 & 2,5875 & $3,4433^{\mathrm{a}}$ \\
\hline 7 & 3,2875 & 2,8900 & 2,4575 & 3,8950 & 2,7825 & 2,4600 & $2,9620^{\mathrm{ab}}$ \\
\hline $\begin{array}{c}\text { Rerata } \\
\text { Dosis }\end{array}$ & $3,2756^{\mathrm{a}}$ & $3,2412^{\mathrm{a}}$ & $2,9618^{\mathrm{a}}$ & $2,9987^{\mathrm{a}}$ & $2,8725^{\mathrm{a}}$ & $2,5718^{\mathrm{a}}$ & \\
\hline
\end{tabular}

Pada tabel di atas dapat dilihat bahwa berdasarkan hari pengamatan, maka pada hari ke-5 rerata sel darah merah mencit setelah diberikan ekstrak daun A. conyzoides L. menunjukkan jumlah yang paling tinggi yaitu $3,4433 \times 10^{6} / \mathrm{mm}^{3}$ sel eritrosit. Apabila dilihat berdasarkan dosis pemberian ekstrak daun $A$. conyzoides L. maka sel darah merah mencit tidak menunjukkan perbedaan yang signifikan antara kelompok perlakuan dengan kelompok kontrol.

Tabel 4 Rerata Jumlah Sel Darah Merah Mencit Setelah Diberi Ekstrak Akar Ageratum conyzoides L.

\begin{tabular}{|c|c|c|c|c|c|c|c|}
\hline \multirow{2}{*}{ Hari } & \multicolumn{6}{|c|}{ Sel Darah Merah $\left(\times 10^{6} / \mathrm{mm}^{3}\right.$ darah $)$} & \multirow{2}{*}{$\begin{array}{c}\text { Rerata } \\
\text { Hari }\end{array}$} \\
\hline & \multicolumn{2}{|c|}{ Dosis Ekstrak Akar (mg/kg BB) } & 28 & $\frac{(\mathrm{mg} / \mathrm{kg}}{42}$ & 56 & 70 & \\
\hline 1 & 3,1375 & 2,7725 & 3,6675 & 4,0325 & 2,0100 & 3,4300 & $3,1750^{\mathrm{a}}$ \\
\hline 3 & 2,2750 & 1,6650 & 2,1100 & 2,1225 & 1,9800 & 2,0000 & $2,0254^{\mathrm{c}}$ \\
\hline 5 & 2,7925 & 2,1500 & 2,2100 & 2,0525 & 3,0025 & 1,8300 & $2,3396^{\mathrm{bc}}$ \\
\hline 7 & 2,7175 & 2,7550 & 2,2350 & 2,2875 & 1,9025 & 3,1050 & $2,5004^{b}$ \\
\hline $\begin{array}{c}\text { Rerata } \\
\text { Dosis }\end{array}$ & $2,7306^{\mathrm{a}}$ & $2,3356^{\mathrm{a}}$ & $2,5556^{\mathrm{a}}$ & $2,6237^{\mathrm{a}}$ & $2,2237^{a}$ & $2,5912^{\mathrm{a}}$ & \\
\hline
\end{tabular}

Pada Tabel 4 dapat dilihat bahwa berdasarkan hari pengamatan, maka rerata sel darah merah mencit setelah diberikan ekstrak akar $A$. conyzoides $\mathrm{L}$. terlihat berbeda signifikan antara hari ke-1 dengan hari ke-3, 5, dan 7. Pada hari ke-1 sel darah merah menunjukkan jumlah yang paling tinggi yaitu $3,1750 \times 10^{6} / \mathrm{mm}^{3}$ sel eritrosit. Pada hari ke 3 terlihat ada penu-runan sel darah merah, namun meningkat lagi pada hari ke-5 dan ke-7. Apabila dilihat ber-dasarkan dosis pemberian ekstrak akar A. conyzoides L. maka sel darah merah mencit tidak menunjukkan perbedaan yang signifikan antara kelompok perlakuan dengan kelompok kontrol.

Pemberian esktrak daun dan akar A. conyzoides L. tidak berpengaruh terhadap jumlah sel darah merah. Dalam hal ini bahan aktif yang terdapat pada $A$. conyzoides $\mathrm{L}$. dapat diedarkan oleh sel darah merah ke seluruh tubuh secara sempurna. Telah diketahui bahwa sel darah merah berperan dalam mengedarkan zatzat makanan dari usus ke sel-sel tubuh, transportasi sisa-sisa metabolism tubuh kea latalat ekskresi tubuh, transportasi air, dan elektrolit. Dengan memiliki fungsi tersebut, darah mempunyai peranan penting mempertahankan homeostasis tubuh yang meliputi keseimbangan cairan tubuh, $\mathrm{pH}$, maupun suhu tubuh, transpotrasi enzim-enzim dan hormone, pertahanan tubuh terhadap infiltasi benda-benda asing dan mikroorganisme (Guyton dan Hall, 1997)

Data hasil perhitungan jumlah sel darah putih (BDP) mencit setelah diberikan ekstrak daun dan akar $A$. conyzoides $\mathrm{L}$. disajikan pada Tabel 5 dan Tabel 6 
Tabel 5 Rerata Jumlah Sel Darah Putih Mencit Setelah Diberi

Ekstrak Daun Ageratum conyzoides L.

\begin{tabular}{cccccccc}
\hline & \multicolumn{6}{c}{ Sel Darah Putih $\left(\mathrm{x} 10^{3} / \mathrm{mm}^{3}\right.$ darah $)$} & \multirow{2}{*}{ Rerata } \\
\cline { 2 - 6 } Hari & \multicolumn{9}{c}{ Dosis Ekstrak Akar $(\mathrm{mg} / \mathrm{kg} \mathrm{BB})$} & \\
\cline { 2 - 6 } & 0 & 14 & 28 & 42 & 56 & 70 & $2,7145^{\mathrm{a}}$ \\
3 & 3,3125 & 3,0875 & 2,4250 & 2,4875 & 2,5375 & 2,4375 & $2,7312^{\mathrm{a}}$ \\
5 & 3,2000 & 2,9500 & 2,0375 & 2,7625 & 3,0000 & 2,4375 & $2,4291^{\mathrm{a}}$ \\
7 & 1,8375 & 2,5875 & 1,8000 & 2,7500 & 3,2375 & 2,3625 & $2,8208^{\mathrm{a}}$ \\
Rerata & 2,7375 & 3,3750 & 2,4250 & 2,9250 & 3,1625 & 2,3000 & \\
Dosis & $2,7718^{\mathrm{a}}$ & $3,0000^{\mathrm{a}}$ & $2,1718^{\mathrm{a}}$ & $2,7312^{\mathrm{a}}$ & $2,9843^{\mathrm{a}}$ & $2,3843^{\mathrm{a}}$ & \\
\hline
\end{tabular}

Pada tabel di atas dapat dilihat bahwa berdasarkan hari pengamatan, maka rerata sel darah putih mencit setelah diberikan ekstrak daun A. conyzoides L. tidak menunjukkan perbedaan jumlah yang signifikan antara hari ke 1, 3, 5, dan 7. Demikian pula apabila dilihat berdasarkan dosis pemberian ekstrak daun $A$. conyzoides $\mathrm{L}$. maka sel darah merah mencit tidak menunjukkan perbedaan yang signifikan antara kelompok perlakuan dengan kelompok kontrol.

Tabel 6 Rerata Jumlah Sel Darah Putih Mencit Setelah Diberi Ekstrak Akar Ageratum conyzoides L.

\begin{tabular}{|c|c|c|c|c|c|c|c|}
\hline \multirow{3}{*}{ Hari } & \multirow{2}{*}{\multicolumn{6}{|c|}{$\frac{\text { Sel Darah Putih }\left(\times 10^{3} / \mathrm{mm}^{3} \text { darah }\right)}{\text { Dosis Ekstrak Akar }(\mathrm{mg} / \mathrm{kg} \mathrm{BB})}$}} & \multirow{3}{*}{$\begin{array}{c}\text { Rerata } \\
\text { Hari } \pm \text { sd }\end{array}$} \\
\hline & & & & & & & \\
\hline & 0 & 14 & 28 & 42 & 56 & 70 & \\
\hline 1 & 3,3875 & 2,7750 & 2,4625 & 3,5375 & 3,8000 & 3,2125 & $3,1958^{\mathrm{a}}$ \\
\hline 3 & 1,6750 & 1,9875 & 2,5750 & 1,5875 & 1,4375 & 2,2750 & $1,9223^{\mathrm{c}}$ \\
\hline 5 & 2,2875 & 2,0625 & 2,6750 & 2,4125 & 2,9250 & 1,5875 & $2,3250^{\mathrm{bc}}$ \\
\hline 7 & 2,2375 & 2,3125 & 2,8875 & 2,7750 & 2,9625 & 3,1625 & $2,7229^{\mathrm{ab}}$ \\
\hline Rerata & $2,3969^{\mathrm{a}}$ & $2,2843^{\mathrm{a}}$ & $2,6500^{\mathrm{a}}$ & $2,5781^{\mathrm{a}}$ & $2,7812^{\mathrm{a}}$ & $2,5593^{\mathrm{a}}$ & \\
\hline
\end{tabular}

Pada tabel di atas dapat dilihat bahwa berdasarkan hari pengamatan, maka rerata sel darah putih mencit setelah diberikan ekstrak akar A. conyzoides $\mathrm{L}$. terlihat berbeda signifikan antara hari ke-1 dengan hari ke-3, 5, dan 7. Pada hari ke-1 sel darah putih menunjukkan jumlah yang paling tinggi yaitu $3,1958 \times 10^{3} / \mathrm{mm}^{3}$ sel eritrosit. Pada hari ke 3 terlihat ada penurunan sel darah putih, namun meningkat lagi pada hari ke-5 dan ke-7. Apabila dilihat berdasarkan dosis pemberian ekstrak akar A. conyzoides L. maka sel darah merah mencit tidak menunjukkan perbedaan yang signifikan antara kelompok perlakuan dengan kelompok kontrol.

Berdasarkan hasil di atas dapat dikatakan bahwa nilai jumlah sel darah putih pada mencit yang diberikan esktrak daun dan akar masih dalam katagori normal. Hal tersebut dapat dijelaskan bahwa pemberian ekstrak daun $A$. conyzoides L. tidak bersifat toksik, sehingga tubuh meresponnya sebagai bahan yang dapat menjaga homoestasis tubuh. Apabila ekstrak $A$. conyzoides L. bersifat racun maka secara langsung tubuh akan merespon dengan memfungsikan sel darah putih sebagai barrier pertahanannya. Telah diketahui bahwa sel darah putig berperan dalam sistem pertahanan tubuh terutama untuk melawan agen infeksi yang masuk ke dalam tubuh (Delman dan Brown, 1988).

Data hasil perhitungan kadar hemoglobin mencit setelah diberikan ekstrak daun dan akar A. conyzoides L. disajikan pada Tabel 7 dan Tabel 8.

Tabel 7 Rerata Kadar Hemoglobin Mencit Setelah Diberi Ekstrak Daun Ageratum conyzoides L.

\begin{tabular}{|c|c|c|c|c|c|c|c|}
\hline \multirow[t]{2}{*}{ Hari } & \multicolumn{6}{|c|}{ Kadar Hemoglobin (g/dl) } & \multirow{2}{*}{$\begin{array}{c}\text { Rerata } \\
\text { Hari }\end{array}$} \\
\hline & 0 & 14 & 28 & 42 & 56 & 70 & \\
\hline 1 & 21,20 & 21,87 & 21,85 & 21,55 & 19,80 & 21,15 & $21,23^{\mathrm{a}}$ \\
\hline 3 & 18,90 & 15,65 & 16,00 & 19,20 & 16,25 & 18,00 & $17,33^{\mathrm{b}}$ \\
\hline 5 & 14,40 & 18,00 & 12,50 & 12,20 & 12,50 & 11,00 & $13,43^{\mathrm{c}}$ \\
\hline 7 & 9,85 & 12,50 & 9,65 & 11,00 & 10,50 & 11,10 & $10,76^{\mathrm{d}}$ \\
\hline $\begin{array}{c}\text { Rerata } \\
\text { Dosis }\end{array}$ & $16,08^{\mathrm{ab}}$ & $17,00^{\mathrm{a}}$ & $15,00^{\mathrm{b}}$ & $15,98^{\mathrm{ab}}$ & $14,76^{\mathrm{b}}$ & $15,31^{\mathrm{ab}}$ & \\
\hline
\end{tabular}


Pada tabel di atas dapat dilihat bahwa berdasarkan hari pengamatan, maka rerata kadar hemoglobin mencit setelah diberikan ekstrak daun A. conyzoides L. menunjukkan perbedaan jumlah yang signifikan antara hari ke 1, 3, 5, dan 7. Pada hari pengamatan ke-1 kadar hemog-lobin mencit terlihat lebih tinggi yaitu $21,23 \mathrm{~g} / \mathrm{dl}$. Selanjutnya pada hari ke-3, 5 dan 7 kadar hemoglobin mencit tampak menurun. Apabila dilihat berdasarkan dosis pemberian ekstrak daun $A$. conyzoides L. maka kadar hemoglobin mencit mencit tidak menunjukkan perbedaan yang signifi-kan antara kelompok perlakuan dengan kelompok kontrol. Namun pada dosis $14 \mathrm{mg} / \mathrm{kg}$ kadar hemoglobin berbeda signifikan lebih tinggi dibandingkan dengan dosis $56 \mathrm{mg} / \mathrm{kg}$. Kadar hemoglobin tertinggi yaitu pada kelompok mencit yang diberikan ekstrak daun A. conyzoides L. 14 $\mathrm{mg} / \mathrm{kg}$ yaitu $17,00 \mathrm{~g} / \mathrm{dl}$.

Tabel 8 RerataKadar Hemoglobin Mencit Setelah Diberi Ekstrak Akar Ageratum conyzoides L.

\begin{tabular}{cccccccc}
\hline & \multicolumn{4}{c}{ Kadar Hemoglobin (g/dl) } \\
Hari & 0 & 14 & 28 & 42 & 56 & 70 & Rerata $^{\text {Hari }}$ \\
\hline 1 & 17,90 & 18,25 & 20,15 & 18,80 & 18,30 & 18,65 & $18,68^{\mathrm{a}}$ \\
3 & 18,90 & 17,05 & 18,70 & 18,05 & 16,25 & 18,00 & $17,83^{\mathrm{a}}$ \\
5 & 9,55 & 11,25 & 9,30 & 10,30 & 11,45 & 8,55 & $10,07^{\mathrm{c}}$ \\
7 & 12,55 & 13,15 & 10,80 & 10,00 & 8,95 & 10,95 & $11,07^{\mathrm{b}}$ \\
Rerata & $14,73^{\mathrm{a}}$ & $14,93^{\mathrm{a}}$ & $14,74^{\mathrm{a}}$ & $14,29^{\mathrm{a}}$ & $13,74^{\mathrm{a}}$ & $14,04^{\mathrm{a}}$ & \\
Dosis & & & & & & & \\
\hline
\end{tabular}

Pada tabel di atas dapat dilihat bahwa berdasarkan hari penga-matan, maka rerata kadar hemoglobin mencit setelah diberikan ekstrak akar $A$. conyzoides L. terlihat berbeda signifikan antara hari ke-1 dan 3 dengan hari ke-5 dan 7. Pada hari ke-1 kadar hemoglobin mencit menunjukkan jumlah yang paling tinggi yaitu 18,68 g/dl. Pada hari ke-3, 5, dan 7 terlihat penurunan kadar hemoglobin mencit. Apabila dilihat berdasarkan dosis pemberian ekstrak akar $A$. conyzoides L. maka kadar hemoglobin mencit tidak menunjukkan perbedaan yang signifikan an-tara kelompok perlakuan dengan kelompok kontrol.
Kadar hemoglobin dalam tubuh dipengaruhi jumlah sel darah merah. Dalam hal ini pemberian ekstrak akar dan daun A. conyzoides $\mathrm{L}$. tidak berpengaruh terhadap sel darah merah, maka kadar hemoglobin pun tidak mengalami perubahan yang signifikan. Menurut Evan et al. (2006) bahwa pada hewan dan umur yang sama berkorelasi positif antara jumlah sel darah merah, kadar hemoglobin dan nilai hema-tokrit.

Data hasil perhitungan berat organ hati dan ginjal mencit setelah diberikan ekstrak daun dan akar A. conyzoides L. disajikan pada Tabel 9 dan Tabel 10.

Tabel 9 RerataBerat Organ Mencit Setelah Diberi Ekstrak Daun Ageratum conyzoides L.

\begin{tabular}{|c|c|c|}
\hline \multirow{2}{*}{$\begin{array}{c}\text { Konsentrasi Ekstrak } \\
(\mathrm{mg} / \mathrm{kg})\end{array}$} & \multicolumn{2}{|c|}{ Berat Organ (g) } \\
\hline & Hati & Ginjal \\
\hline Kontrol & $2,6750^{\mathrm{ab}}$ & $0,7250^{\mathrm{a}}$ \\
\hline 14 & $2,7250^{\mathrm{ab}}$ & $0,5250^{\mathrm{a}}$ \\
\hline 28 & $2,5500^{\mathrm{b}}$ & $1,0000^{\mathrm{a}}$ \\
\hline 42 & $3,2750^{\mathrm{a}}$ & $0,8750^{\mathrm{a}}$ \\
\hline 56 & $2,8250^{\mathrm{ab}}$ & $0,5000^{\mathrm{a}}$ \\
\hline 70 & $2,4000^{\mathrm{b}}$ & $0,5750^{\mathrm{a}}$ \\
\hline
\end{tabular}


Pada tabel di atas dapat dilihat bahwa rerata berat hati mencit setelah diberikan ekstrak daun A. conyzoides L. selama tujuh hari perlakuan tidak memperlihatkan perbedaan yang signifikan antara kelompok perlakuan dan kelompok kontrol. Namun berat hati mencit yang diberikan dosis $42 \mathrm{mg} / \mathrm{kg}$ ekstrak daun A. conyzoides $\mathrm{L}$. berbeda signifikan lebih berat dibandingkan dengan dosis $28 \mathrm{mg} / \mathrm{kg}$ dan $70 \mathrm{mg} / \mathrm{kg}$. Pada dosis $42 \mathrm{mg} / \mathrm{kg}$ ekstrak daun A. conyzoides $\mathrm{L}$. berat hati mencit memperlihatkan berat yang paling tinggi $3,2750 \mathrm{~g}$. Selanjutnya berat organ ginjal mencit setelah diberikan ekstrak daun $A$. conyzoides L. selama tujuh hari perlakuan tidak memperlihatkan perbedaan yang signifikan antara kelompok perlakuan dan kelompok kontrol. Berat organ ginjal yang tertinggi yaitu pada dosis $28 \mathrm{mg} / \mathrm{kg}$ ekstrak daun A. conyzoides L. sebesar $1,00 \mathrm{~g}$.

Tabel 10 Rerata Berat Organ Mencit Setelah Diberi Ekstrak Akar Ageratum conyzoides $\mathbf{L}$.

\begin{tabular}{ccc}
\hline $\begin{array}{c}\text { Konsentrasi } \\
\text { Ekstrak (mg/kg) }\end{array}$ & \multicolumn{2}{c}{ Berat Organ $(\mathbf{g})$} \\
Hoti & Ginjal \\
\hline Kontrol & $1,5000^{\mathrm{c}}$ & $0,3000^{\mathrm{c}}$ \\
28 & $1,8750^{\mathrm{bc}}$ & $0,3750^{\mathrm{abc}}$ \\
42 & $2,4250^{\mathrm{a}}$ & $0,3250^{\mathrm{bc}}$ \\
56 & $2,1000^{\mathrm{ab}}$ & $0,4500^{\mathrm{a}}$ \\
70 & $2,1250^{\mathrm{ab}}$ & $0,4250^{\mathrm{ab}}$ \\
\hline
\end{tabular}

Pada tabel di atas dapat dilihat bahwa rerata berat hati mencit setelah diberikan ekstrak akar A. conyzoides L. selama tujuh hari perlakuan memperlihatkan perbedaan yang signifikan antara dosis 28,42 dan $56 \mathrm{mg} / \mathrm{kg}$ dengan kelompok kontrol. Selanjutnya berat hati mencit setelah diberikan ekstrak akar A. conyzoides L. pada dosis $28 \mathrm{mg} / \mathrm{kg}$ berbeda signifikan lebih berat dengan kelompok mencit yang diberikan ekstrak pada $14 \mathrm{mg} / \mathrm{kg}$ dan $70 \mathrm{mg} / \mathrm{kg}$. Berat organ hati tertinggi dapat dilihat pada dosis $28 \mathrm{mg} / \mathrm{kg}$.

Selanjutnya berat organ ginjal mencit setelah diberikan ekstrak daun A. conyzoides $\mathrm{L}$. selama tujuh hari perlakuan memperlihatkan perbedaan yang signifikan antara dosis 42 dan $56 \mathrm{mg} / \mathrm{kg}$ dengan kelompok kontrol dan kelompok mencit yang diberikan dosis $70 \mathrm{mg} / \mathrm{kg}$. Berat organ ginjal yang tertinggi yaitu pada dosis $42 \mathrm{mg} / \mathrm{kg}$ ekstrak daun A. conyzoides $\mathrm{L}$. sebesar $0,450 \mathrm{~g}$.

Pemberian perlakuan dosis ekstrak daun dan akar A. conyzoides L. sebesar 14, 28, 42, 56, $70 \mathrm{mg} / \mathrm{kg}$ masih dapat di respon baik oleh tubuh mencit, dimana setelah masuk ke dalam pere- daran darah, yang selanjutnya akan di bawa ke hati. Di hati bahan semua zat yang dibawa oleh darah akan disintesis menjadi molekul-molekul yang lebih sederhana yang siap untuk diedarkan ke seluruh tubuh. Pemberian ekstrak daun dan akar A. conyzoides $\mathrm{L}$ tidak memberikan beban kerja yang berat buat hati sehingga fungsi hati dapat berjalan normal dan tidak mempengaruhi berat hati.

Pemberian perlakuan dosis ekstrak daun dan akar A. conyzoides L. sebesar 14, 28, 42, 56, $70 \mathrm{mg} / \mathrm{kg}$ masih dapat di respon baik oleh tubuh mencit, dimana setelah masuk ke dalam peredaran darah dan diedarkan ke seluruh tubuh, sisa metabolismenya akan dibuang melalui proses filtrasi di ginjal. Selama tujuh hari pengamatan proses ekskresi yang dikerjakan oleh ginjal dapat berlangsung normal, sehingga pemberian ekstrak daun dan akar $A$. conyzoides L tidak berpengaruh terhadap fungsi ginjal.

\section{KESIMPULAN}

Berdasarkan hasil penelitian dapat dibuat beberapa kesimpulan yaitu :

1. Pemberian ekstrak daun dan akar Ageratum conyzoides L. sebesar 14, 28, $42,56,70 \mathrm{mg} / \mathrm{kg}$ BB tidak mempengaruhi berat badan mencit, sel darah merah, sel darah putih, hemoglobin, berat ginjal dan berat hati.

2. Pemberian ekstrak daun dan akar Ageratum conyzoides L. pada hari ke-1, 3, 5 dan 7 tidak berpengaruh terhadap berat badan mencit. Jumlah sel darah merah meningkat pada hari ke-5 $\left(3,443 \times 10^{6-}\right.$ $/ \mathrm{mm}^{3}$ ) akibat pemberian ekstrak daun. Akiba pemmberian esktrak akar, sel darah merah menurun pada hari ke-3 namun naik lagi pada hari ke-5 dan 7. Jumlah sel darah putih tidak berpengaruh pada pemberian ektrak daun, namun pada ekstrak akar menurun. Kadar hemoglobin menurun akibat pemberian ekstrak akar dan daun seiring waktu pengamatan, namun masih pada batas yang normal.

\section{DAFTAR PUSTAKA}

Dellman, H.D, dan Brown, E.M. 1988. Buku Tek Histologi Veteriner. Diterjemahkan oleh : R. Hartono. Penerbeit : Universitas Indonesia (UI Press). 
Jakarta. Terjemahan dari : Texbook of Veterinary Histology Ed. 3.

Evans, DM., Frazer, IH. and Martin, NG. (2006). http: //j ap .p h y si ol ogy .org/cg i/conte nt/abstract/52/1/168 [1 Agustus 2007]

Firdaus, G. I. (2010). Uji Toksisitas Akut Ekstrak Meniran (Phyllanthus niruri) Terhadap Hepar Mencit BALB/C. Karya Tulis Ilmiah Fakultas Kedokteran Universitas Diponegoro.

Guyton, AC dan Hall JE. (1997). Buku Ajar Fisiologi Kedokteran. Ed ke-9. Diterjemahkan oleh Setiawan I, Tengadi KA, Santoso A. Jakarta: EGC. Terjemahan dari: Textbook of Medical Physiology.

Hasibuan, P.A. dan Nainggolan, M. (2007). "Penentuan Sifat Kimia Fisika Senyawa Alkaloid Hasil Isolasi dari Daun
Bandotan (Ageratum conyzoides Linn.)". Jurnal Penelitian MIPA. 1, (1), 20 - 22.

Heyne, K. 1987. Tumbuhan Berguna Indonesia. Terjemahan Balitbang Kehutanan, Jakarta.

Ita, S.O., Etim, O.E., Ben, E.E., and Ekpo, O.F. (2007). "Haematopoietic Properties of Ethanolic Leaf Extract of Ageratum conyzoides (Goat Weed) in Albino Rats". Nigerian Journal of Physiological Sciences. 22, $(1-2), 83-87$.

Retno, Andaru, Handayani. (2009). Uji Sitotoksik Ekstrak Petroleum Eter Herba Bandotan (Ageratum conyzoides L.) Terhadap Sel T47D Dan Profil Kromatografi Lapis Tipis. Skripsi Fakultas Farmasi Universitas Muhammadiyah Surakarta: Tidak diterbitkan. 